\title{
Brentano and Mauthner on grammatical illusions
}

Denis Seron (FNRS, Univ. of Liège)

\begin{abstract}
:
This paper aims to suggest that Brentano's theory of intentionality, at least in its later formulation, is not only about mind and also belongs to a tradition of deconstructing language that includes prominent figures of Austrian and German philosophy such as Mach, Vaihinger, and Wittgenstein. In order to establish this, the author explores some differences and similarities between this theory and Fritz Mauthner's critique of language. He argues that the very starting point of both is one and the same fact: the failure of existential generalization.
\end{abstract}

In the current literature Brentano's name is usually associated with British empiricism, the Aristotelian tradition, and the so-called "Austrian semantic turn". This paper seeks to suggest a convergence with another tradition within Austrian philosophy - namely the critique of language developed, among others, by Mach, Mauthner, Karl Kraus, the German Vaihinger, and Wittgenstein. My starting hypothesis is that, despite significant differences, the late Brentano's approach to grammatical illusions has a great deal in common with Fritz Mauthner's critique of language.

One of the first authors who noticed the similarities between the two philosophers was Oskar Kraus. In his Self-Presentation from 1929, Kraus says that the late Brentano's search for a criterion for autosemantic expressions clearly belongs to the same movement as the critique of language of Vaihinger and Mauthner (Kraus 1929: 16, cited in Weiler 1970: 297). The connections between Brentano and Mauthner have been investigated at length later, above all by Liliana Albertazzi $(1986,1989,1990)$ and, to a lesser extent, by Gershon Weiler (1970). Some other commentators have drawn attention to them without further discussion. For 
example, Cesalli and Mulligan rightly claim that Brentano's critique of language was an "opening shot of the Austrian critique of language to which Marty, Mauthner, Oskar and Karl Kraus and Wittgenstein will all contribute" (Cesalli \& Mulligan 2017: 257). This paper is an attempt to bring forward some new or newly formulated ideas on the relation between Brentano and Mauthner.

\section{Critique of language}

Fritz Mauthner terms his philosophical project as a whole "critique of language" (Sprachkritik). In his view, the philosopher's sole task is to liberate us from the illusions of language. The basic idea is twofold. First, language necessarily generates grammatical illusions that are pervasive and play a central role in science, philosophy, religion, politics, and everyday life. Secondly, Mauthner defends the extreme skeptical view to the effect that these illusions make language in general "inadequate for knowing the world and hence for communicating knowledge" (Mauthner 1901-2, Vol. 1: 122). We cannot enrich our knowledge of the world through language; all language consists of only tautologies (Mauthner 1901-2, Vol. 1: 93; Weiler 1958: 82; Weiler 1970: 236 ff.).

Brentano, too, holds that grammar spontaneously generates illusions, and that an essential part of the philosopher's task is to dissolve these illusions through philosophical clarification. In his late correspondence with Marty, he calls these grammatical illusions "entia rationis" or "fictions", as opposed to entia realia or things (Brentano 1977: 324). Grammar leads us to introduce illegitimate entities - fictions - which as such are no more than entia linguae, or entia elocutionis in Marty's terminology (Brentano 1977: 191). It is unclear whether Brentano defended this view only in his reist period or also in earlier writings. Some commentators, for example Massimo Libardi (1996: 68), claim that the struggle against entia rationis thus conceived is basic not only to Brentano's late reism, but to his work as a whole.

Brentano's line of reasoning can be summed up as follows: First, the theory of intentionality teaches us that not all phenomena really exist. Some thought objects are real things and some are fictions, that is, possible correlates of synsemantic expressions. Second, grammar is deceiving because synsemantic expressions are grammatically indistinguishable from autosemantic expressions. A fictitious name can have the same grammatical function within a sentence as the name of a real thing. For example you can say "A round square is impossible" or "Freedom is better than slavery". This may lure you into the illusion that round squares and freedom are real things. Since the term "round square" is the grammatical subject of the sentence "a round square is impossible", it looks as if the round square were a thing that has the property of being impossible. However, a round square is not a real thing, but a fiction. We mistake it for a real thing because the grammatical function of the term "round square" in the sentence prompts us to do so. Actually, Brentano argues, there is "no more than a specific 
linguistic phrasing that leads one to the fiction of a new being" (Brentano 1977: 172). Thirdly and finally, we need a criterion for distinguishing entia rationis from entia realia. Since synsemantic expressions are grammatically indistinguishable from autosemantic expressions, this criterion must come from elsewhere than from grammar itself. In Brentano's view, it is psychological analysis that enables us to sort out synsemantic from autosemantic expressions and thus to discriminate fictions from real things (Brentano 1977: 173).

The non-grammatical criterion the late Brentano proposes for distinguishing entia rationis from entia realia is, at least in part, psychological. It is stated as follows: "Every object of a presentation, if it exists, is real" (Brentano 1977: 380). This criterion sets two conditions for something being an ens reale. First, there must be a presentation (or intuition, as Brentano also says): "It is impossible, claims Brentano, to have a presentation without having a presentation of something. And this 'something' means something real' (Brentano 1977: 173). Being real is a necessary condition for being presented. In other words: If an intentional object is presented, then it must be real; if it is an ens rationis or fiction, then it cannot be presented and one or more acts of the two other classes can be identified through psychological analysis. Thus, wherever psychological analysis uncovers a genuine presentation, that is, an act that is not reducible to a judgment or feeling, the object presented must be real. This first requirement leads us to deny that abstract terms like "color" and "space" as well as dispositional, negative, and most mathematical expressions denote entia realia. ${ }^{1}$

The second condition is that the ens reale must actually exist. It is not easy to work out exactly what this further requirement adds to the first one. On my interpretation, Brentano's aim might be to confine entia realia to just the things given in present inner perception. It is well known that the late Brentano defended a form of presentism according to which, as he declares in his posthumous Versuch über die Erkenntnis, “'being' means 'present'” ('Seiend' heisst soviel als 'gegenwärtig') (Brentano 1970: 27). Since only what is perceived, that is, innerly perceived, is present, it follows from this that only mental phenomena can be present and hence real, while other phenomena must be fictions.

\footnotetext{
${ }^{1}$ Albertazzi (2006: 177-178) provides the following list of entia rationis: "1. All abstract nouns like 'extension', 'colour', 'thought', 'space', 'time', given that in reality there exists only the extended, the coloured, the thinking, something spatial, temporal. 2. Nouns expressing possibility like 'capacity for thought', 'capacity for movement'. 3. The contents of presentations like 'the non-being of the centaur is', 'a non-existent centaur is'. 4. Whatever belongs to the Aristotelian category of ens per accidens. For example, in 'this man is armed' the predicate has solely the meaning of an extrinsic determinatio, given that there is no real identity between subject and predicate. 5. Whatever belongs to the Aristotelian category of ens tamquam verum. For example, one can only say that 'an oak is' if one recognizes an oak; or 'the non-being of the centaur' only means that one denies a centaur. 6. All scientific fictions, like unreal numbers, fractions, infinity and infinitesimals in mathematics."
} 
In any case, there are obvious similarities between these views and Mauthner's critique of language. Both Brentano and Mauthner hold that we all cling to fictions as if they were real objects, that the reason for this is grammatical, and that part or whole of the philosopher's job is to denounce such grammatical illusions. This corresponds to what Mauthner calls "word fetishism". Some expressions are misleadingly used in such a way that their surface grammar function or category induces us to take them as denoting real things, while they actually don't: "Most people have the weakness to believe that, since a word is present, it must be a word for something, and that, since a word is present, something real must correspond to it" (Mauthner 1901-2, Vol. 1: 159). This means, in Brentano's terms, that some expressions are used as if they corresponded to presentations and thus to real things, while they actually don't.

\section{Language doesn't refer to the outside world}

I come now to Mauthner's skepticism. His most central view about language is that language does not refer to the world. Mauthner denies that language in general has a referential function at all. In his view, language has instead mainly two functions, a practical and an expressive one. First, words serve to register memories within a linguistic community. The memories of a people are stored in its language just as the memories of an individual are stored in her brain (Mauthner 1901-2, Vol. 1: 179, 184-185; Mauthner 1906: 26-27). Secondly, words have a poetical or expressive function which is carried out by a small number of original thinkers. Such-and-such an experience A puts the original thinker in a specific mood (Stimmung), that is, brain state. The original thinker then associates this brain state with such-and-such a word or combination of words which is commonly associated with another experience $\mathrm{B}$, so that the linguistic community can then use this new association in order to register experiences: the word used by the poet can now be used to register both experiences A and B, and then the experience A only. In Mauthner's view, the expressive function is prior to the mnemonic function. The vocabulary of a language is constituted by poetical expressions that have lost their expressive value.

To sum up: We associate a given word with some specific memories because our linguistic community prescribes to do so, and our linguistic community prescribes to do so because in the past a poet associated this word with a specific mood or brain state which had until then been associated with other words and memories. Words are primarily signs for moods, and it is only secondarily that they are taken to denote objects, namely those objects which cause the corresponding mood in the poet's mind. For this reason, Mauthner claims, "words never produce knowledge, they are just tools for poetry" (Mauthner 1901-2, Vol. 1: 151).

The key point here is that language, for Mauthner, neither refers nor enables us to know reality. The ultimate function of language is solely expressive or aesthetic: language expresses 
moods or brain states that are associated with our presentations of the real world - and this association should not be conceived of as a relation of reference. There exist no expressions that denote real objects. Hence, language and knowledge are mutually incompatible and knowledge is impossible.

In Mauthner's view, words and concepts have no direct connection with presentations; they just express aesthetic moods that are incidentally associated with presentations. Of course, Brentano was not a skeptic. Unlike Mauthner, he did believe that some linguistic expressions really denoted entia realia, namely present mental phenomena. While Brentano claims that "all our concepts derive from intuitions" (Brentano 1977: 329), Mauthner protests that "a concept amounts not to a real intuition, but only to the beautiful appearance of an intuition" (Mauthner 1901-2, Vol. 1: 123-124).

Nevertheless, Mauthner's views may be regarded as close to Brentano's in some respects. Both philosophers deny that language refers to external reality. In the Logikkolleg, Brentano characterizes language as a "sign of thinking" (Zeichen des Denkens) (EL80, 12.978[9]; see Cesalli \& Mulligan 2017: 257). This characterization should be taken in a radical sense. In his monography on Brentano posthumously published by Franziska Mayer-Hillebrand, Alfred Kastil paraphrases Brentano's claim as follows: For Brentano, “language is not a direct sign for things existing outside the speaker, but a sign for what goes on in her, in her soul" (Kastil 1951: 100).

Both Brentano and Mauthner deny that our language denotes external reality; both claim that language ultimately has to do with inner life, namely moods or present mental acts. The difference is that, for Brentano, language in some cases really denote internal things, while for Mauthner language never denotes anything.

I'd like now to review three kinds of entities that both Brentano and Mauthner reject as linguistic fictions, namely intentional objects, the ego, and general objects.

\section{Three kinds of "word fetishes"}

Some commentators view (rightly in my opinion) Brentano's rejection of entia rationis as a consequence of his theory of intentionality (Huemer 2018). What is more, it is plausible to say that the approach just outlined is already at the basis of Brentano's theory of intentionality in the Psychology of 1874 . The basic tenet of the theory of intentionality is that present mental phenomena really exist and that they necessarily contain in them non-existent phenomena, namely physical or mental phenomena that are not presently experienced by the subject. Brentano's theory of intentionality stems from his rejection of the view that all phenomena are objects of perception, that is, given as really existent in the present. What Brentano advocates instead is his theory of intentionality, namely this view: not all phenomena are 
perceived; most of them - all physical and non-present mental phenomena - are rather imagined, remembered, conceptually thought, and the like. Those phenomena which are not perceived do not really exist in the present, although they do presently appear within mental acts insofar as they are presently imagined, remembered, etc.

Thus, Brentano's purpose in his theory of intentionality is to acknowledge and explain the fact that most phenomena are objects although they do not really exist. In other words: most of the objects that we represent and designate by nouns are inexistent objects. The use of a noun creates in us the illusion that a represented object exists outside of us. In the 1874 Psychology, Brentano claims that the existence of the external world is no more than "a fiction to which no reality of any sort corresponds" (eine Fiktion, der keinerlei Wirklichkeit entspricht) (Brentano 1973: 15-16; Engl. transl.: 10-11). And most importantly, Brentano, like Mauthner, holds that this fiction is of a linguistic nature. In a famous letter dated March 1905, he declares that the intentional object of a representation is not an existing object to which the representation corresponds, but merely the "linguistic correlate" of an intentional verb (Brentano 1977: 120).

The fact that a mental act can have an inexistent object is usually called "representational opacity" and considered to be a constitutive property of intentionality. This property can be characterized as follows: It is possible that there exists a representation or intentional act $\mathrm{x}$ such that $\mathrm{x}$ represents an object $\alpha$ and $\alpha$ does not exist. The idea is that the verbs expressing intentional acts grammatically require a correlate - an $\alpha$ - and that this grammatical requirement sometimes misleads us into postulating an existing entity that is denoted by the name " $\alpha$ ".

We could express the same idea by saying that Brentano here seeks to show that the rule in virtue of which one infers from "x represents $\alpha$ " to " $\alpha$ exists" is not valid. In other words: The rule of existential generalization is not valid for intentional sentences. It is not true that, from the existence of an act that has $\alpha$ as its object, one can safely infer that $\alpha$ exists. It is for this reason that it makes sense to regard Brentano's rejection of entia rationis as a consequence of his theory of intentionality. A "fiction", in Brentano's sense of the word, is precisely something whose existence is erroneously inferred from the fact that it is presented and linguistically expressed by a name. Therefore, in a way at least, it makes sense to view Brentano's theory of intentionality as part of a more general project in the vein of Mauthner's critique of language.

The illusion Brentano seeks to dispel through his theory of intentionality is very similar to what Mauthner calls “word fetishism”. In his Beiträge (Mauthner 1901-2, Vol. 1: 160 ff.), Mauthner says that the main task of the Sprachkritik is to warn us against "word fetishism", and defines "word fetishism" as the error consisting in inferring from the existence of a name to the existence of a named object: "Without a critique of language it will always remain 
possible to infer from the existence of a name to that of the named object, for example from the word deus to the existence of God" (Mauthner 1901-2, Vol. 1: 173).

Most interestingly, the same applies in the case of intentional objects. In his small essay on language published in 1906 in Martin Buber's series "Die Gesellschaft", Mauthner outlines an adverbial approach to intentionality. His idea is that the subject-object distinction is purely linguistic: it is no more than an illusion created by the grammar of the intentional idiom. Actually, sentences of the form "x represents $\alpha$ " never involve any real duality and should be construed in the same way as "x builds a building" or "x plays a game". 2

To illustrate his point, Mauthner tells a funny story from Voltaire's Zadig (Mauthner 1901-2, Vol. 1: 174). Zoroaster has forbidden anyone to eat griffins. His disciples, who all know that griffins don't exist, wonder how their master can have given them such a preposterous commandment. Some argue that the commandment is absurd, while others say: "Griffins must exist, since Zoroaster wants us not to eat them". Zadig says this: "If there are any griffins, then let's not eat them. If there aren't any, then we will eat even less of them. That way we shall all be obeying Zoroaster" (Voltaire 1879: 40, transl. Pearson). What interests us here is the fetishist inference from the intentional sentence "Zoroaster wants us not to eat griffins" to the sentence "griffins exist".

Once again, there remains a great difference between Brentano and Mauthner. The former's claim is not that names never refer to real things. In sharp opposition to Mauthner, he maintains that there are names that really refer to existent objects. As I said, the late Brentano makes a distinction between autosemantic expressions or real names (wahre, eigentliche Namen) and synsemantic expressions. The second category includes many expressions which are grammatically indistinguishable from real names.

Leaving intentionality, I now pass to the two remaining kinds of fictions, namely the ego and concepts.

At first sight, the gulf between the two authors' views about the ego seems unbridgeable. Mauthner was an avowed pupil of Ernst Mach, who undoubtedly had a deep influence on his thought (Berlage 1994). In particular, Mauthner takes up Mach's idea that psychophysical dualism is a discursive construct with no experiential basis for it. By contrast, Brentano

\footnotetext{
${ }^{2}$ See (Mauthner 1906: 72-3; Mauthner 1910: 370), where Mauthner refers to the medieval-scholastic notion of intentional object. Brentano would reject such a formulation due to his commitment to some form of empirical dualism. I will discuss this point later on.
} 
strongly criticizes Mach's psychophysical monism, and his theory of intentionality as a whole can even be viewed as an attempt to rescue dualism from its empiricist critics (Seron 2019). ${ }^{3}$ In spite of this, Mauthner and Brentano defended quite similar views on mental entities. First, both follow up Friedrich-Albert Lange's appeal to a "psychology without soul" (Brentano 1973: 16, Engl. transl.: 11; Mauthner 1922: 136; Mauthner 1906: 7 ff.; Le Rider 2012: 212). Mauthner, like Nietzsche and Mach with his thesis of the "unsalvageable ego", holds that the ego is no more than a grammatical illusion or "fetish word" (Mauthner 1922: 136). Secondly, it seems that Mauthner and Brentano agreed to some extent that mental entities were fictions. In his Vienna lectures on practical philosophy, Brentano claims that not only the ego, but also the entities denoted by psychological categories such as "passion" or "pleasure" are just abstracta or fictions and should be rephrased in mereological terms:

We say, "I have overcome my passion (or my pain)", but we would be more precise if we were to say "My inclination to do my duty overcame my leanings towards pleasure (or my self-pity)" and still more precise - for abstractions are fictions - if we were to say, "One part of myself gained a victory over another part of myself". (Brentano 1952: 251, Engl. transl. 156)

This is not very different from Mauthner's claim that "it is mythology to postulate abstracta (sensation, will) as causes of our mental states" (Mauthner 1922: 136).

The third and last kind of grammatical fictions to be considered are concepts. One of the most salient features of Mauthner's critique of language is his vehement admonition against reifying universals - against what he calls "word realism" (Wortrealismus). ${ }^{4}$ Similarly, Brentano's late reism holds that only individuals can really exist, while universals — "Plato's Idea of an animal, William of Champeaux's general animal, 'the animal' of Husserl" - are but fictions (Brentano 1977: 120, 178; Albertazzi 1990: 223). As said earlier, a fiction or ens rationis in Brentano's sense is basically an ens linguae that is illusorily regarded as a real thing. A fiction can appear wherever a name does not express a concept psychologically

\footnotetext{
${ }^{3}$ For Mauthner's Mach-inspired monism, see, for example, (Mauthner 1910: 370-371). On this difference between Brentano and Mauthner, see (Albertazzi 1986: 43-44; Bredeck 1992: 106 ff.; Le Rider 2012: 242).

4 “The medieval-scholastic realism — which I always call 'word realism' for the sake of distinction — teaches that universals or concepts are something real, that, for example, to the (...) concepts of stallion, horse, quadruped, animal, organism, thing, etc., corresponds in the real world something that is not an individual and yet is really a stallion, a horse, etc." (Mauthner 1901-2, Vol. 3: 616-7). See the related notion of "concept realism" (Begriffsrealismus) in (Vaihinger 1922: 403 ff.).
} 
analyzable into intuitive elements, that is, into individual data. Such names, Brentano argues, create the "illusion" (Täuschung) that "one has concepts whereas actually there are just words" (Brentano 1977: 254). For this reason, psychological analysis centrally serves to demarcate fictions from real things.

\section{Some differences}

Let us now pinpoint some substantive differences between Brentano and Mauthner. As Gershon Weiler has brilliantly showed in his monography on Mauthner, the most central point of difference between the two authors is that Brentano calls for a reformation of language, whereas Mauthner views any such reformation as doomed to fail (Weiler 1970: $296 \mathrm{ff}$.). Brentano thinks that ordinary language is misleading and should be amended; Mauthner claims that every language whatsoever must be misleading because it is in the nature of language to be misleading. For Brentano grammatical illusions are, so to speak, local illusions, while Mauthner rejects language in general as globally illusory.

At least in his latest works, Brentano's overall project is very similar to the project underlying Russell's theory of descriptions (Weiler 1970: 297). Brentano's view is that ordinary language is deceiving and should be replaced by a philosophical language which is not deceiving, namely a language grounded in psychological analysis. Ordinary language is deceiving because it uses expressions that are not referential as if they were referential. For example, Pegasus is the subject of the proposition "Pegasus is a poetical fiction". Since the noun "Pegasus" is the subject of a proposition, it seems that it must denote something that somehow exists. And of course this holds for the proposition "Pegasus doesn't exist" as well. Ordinary language misleads us into believing that even the objects that are correctly said not to exist must somehow exist. Thus, the philosopher's task is to rephrase ordinary language in such a way that every subject of a proposition denotes something that really exists. For example, "Pegasus is a poetical fiction" should be rephrased as "some representations that are experienced by poets and have Pegasus as their content exist". The subject of the proposition — "some representations that..." - here denotes something that really exists.

This task of reformulating ordinary language involves at least two distinct things. First, as Weiler (1970: 297) emphasizes, it involves "sorting out the referring expressions (those which are names of things) from those which are not", that is, among other things, sorting out real from fake names. Secondly, the philosopher rephrases. Brentano here uses the word "translation" (Übersetzung). In a 1907 dictation entitled "Vom Denken und vom ens rationis", he says the task is to "translate in a speech form with real names" (Übersetzung in eine Sprechweise mit eigentlichen Namen) (Brentano 1977: 374). In a letter of 1906, he agrees with Marty that the assertions that accept entia rationis should be rephrased in equivalent assertions that have realia as their objects (Alle Behauptungen, welche Ihre entia rationis 
anerkennen würden, würden in Behauptungen, welche Realia zu Objekten haben, ihr Äquivalent haben) (Brentano 1977: 173).

Mauthner is in total disagreement with such views. His rejection of them rests upon four theses which are extensively discussed in his works:

(1) The first thesis is that the illusions of language are indestructible because they are motivated by practical interests and that these practical interests themselves cannot be eliminated (Mauthner 1906: 81-82).

(2) The second thesis is that the notion of an ideal language is self-contradictory. Mauthner delivered a scathing critique of artificial languages like Esperanto, Volapük, and Leibniz's lingua characteristica, arguing, among other things, that such languages are not different in character from natural languages (Mauthner 1906: $31 \mathrm{ff}$.).

(3) The third thesis is that there is no universal or "philosophical" grammar. ${ }^{5}$ Additionally, Mauthner considers all grammar intrinsically irrational and for this reason rejects the idea of a rational grammar as absurd (Mauthner 1906: 35-36).

(4) Mauthner's fourth and final thesis is that thought is reducible to language. As a nominalist, he claims that there are no such things as concepts or thoughts, and that what many call "thought" is actually but ordinary language (Mauthner 1901-2, Vol. 1: 112, 176). Thus, there is no logic beside and beyond the grammar of ordinary language. The idea of a logical language that expresses thought more clearly and univocally than ordinary language is an illusion.

Obviously, Brentano rejects all these theses. Brentano is not a nominalist (Brentano 1977: 177-8). He believes that conceptual thought is different from language, that the latter can express the former more or less adequately, and therefore that logic — that discipline which prescribes how to express our thoughts adequately — is distinct from the grammar of ordinary language (Albertazzi 1990: 229). In his correspondence with Marty, Brentano holds that grammar (i.e., the grammar of ordinary language) is opposed to logic just as illusion is

\footnotetext{
5 "The human language in itself is an abstractum, an intangible shadow just like the old mental faculties; the human language in itself has absolutely no grammar, and hence no philosophical grammar" (Mauthner 1901-2, Vol. 1: 193). "It would be timely to cease to dream of a philosophical grammar. There is no general grammar, let alone a philosophical one" (Mauthner 1901-2, Vol. 3: 261, transl. by Weiler 1970: 146). Max Scheler was entirely right in his 1914 review of the third volume of Mauthner's Beiträge (second edition), when he opposed to Mauthner Husserl's project of a "pure grammar" (Scheler 1914: 119). Mauthner criticizes Husserl's idea of an "objective-ideal meaning" in (Mauthner 1910: 90). It is also worth noticing that herein lies a major difference between Mauthner's and the Tractarian Wittgenstein's critiques of language (Nájera 2007: 161; Gakis 2012: 89). The question is whether the illusions of ordinary language are constitutive of language in general, or whether a language grounded in logical or psychological analysis can liberate us from them. Also see below on Brentano's distinction between logic and ordinary language grammar.
} 
opposed to reality. A fiction corresponds to a fake name, namely to an expression which is used grammatically as a substantive while this is not its logical function: "The subject function is $<$ here $>$ merely grammatical, not logical" (Brentano 1977: 373-4). Finally, Brentano believes that linguistic expressions have a logical or deep grammar function which is grounded in natural classifications revealed by psychological analysis. Mauthner, like Vaihinger later, rejects the idea of a natural classification as a myth. All our categories of thought come from ordinary language and are purely contingent (Mauthner 1901-2, Vol. 1: 76 ff.; Vaihinger 1922: 312 ff.; Weiler 1970: 228 ff.; Le Rider 2012: 195). ${ }^{6}$

\section{Concluding remarks}

Brentano and Mauthner agree that ordinary language is deceptive insofar as it appears to refer to objects it actually does not refer to. They differ in the conclusions they draw from this fact. Mauthner concludes that language in general never refers to any object whatsoever. Linguistic reference itself is a deceiving appearance: the actual function of language in general is expressive rather than referential. As Le Rider emphasizes, "it is not such-and-such usage of language that Mauthner criticizes, but human language in general. In his view, it is not possible to rectify or amend language so as to make it usable as an instrument for knowledge" (Le Rider 2012: 221-2). By contrast, Brentano, like Russell and others, claims that ordinary language actually refers to other objects than those it appears to refer to. Thus, it must be possible to elaborate a philosophical language that appears to denote what it really denotes a language that explicitly refers to present mental life by univocally articulating concepts directly abstracted from inner perception.

At a more general level, Mauthner's and Brentano's accounts of grammatical illusions may as well be viewed as different ways of dealing with one and the same paradox generated by the radical form of empiricism - something in the vein of Mach's monism of sensation - they both largely adhere to. This paradox may be explained as follows: (1) Knowledge needs to somehow relate to objects that really exist. (2) All that can be said to really exist are the individual data of present perception. (3) As a matter of fact, knowledge (in the normal sense of scientific knowledge) is about objects that are not presently perceived and thus cannot be

\footnotetext{
${ }^{6}$ Albertazzi very rightly opposes Mauthner's “substantial conventionalism" to Brentano's project of a "reform of language" that "in no way reduces the possibility of an ontology, albeit strongly reist, guaranteed in the last analysis by the fact of inner perception relative to the representation of things, and guarantor in its turn of the symbolic translation performed by the common innere Sprachform" (Albertazzi 1989: 149, 154; see also Albertazzi 1996: 103).
} 
said to really exist. In Brentano's view, the physical phenomena studied in the natural sciences do not exist in any sense. Likewise, psychological knowledge deals with either the psychologist's own mental phenomena she remembers or mental phenomena she attributes to others. In either cases the psychologist pretends to "know" objects that she does not presently perceive and thus cannot truly recognize as really existing (Seron 2017a; Seron 2017b).

Such considerations - including the view that "all our representations, sensorially produced, can only relate to the past" (Mauthner 1922: 137) — lead Mauthner to the skeptical conclusion that the concept of knowledge is self-contradictory. Indeed, knowledge conceptually involves both language and referring to reality. ${ }^{7}$ But language is essentially fictitious and thus "impotent as an instrument for knowledge" (Mauthner 1901-2, Vol. 1: 94). Since the objects of knowledge cannot be both real things (1) and fictions (3), knowledge is therefore impossible.

By contrast, Brentano's theory of intentionality may be seen as an attempt to block the skeptical implications of the above paradox. His solution is to distinguish the object of knowledge from its experiential source: knowledge relates to really existing objects that are numerically distinct from the objects it is about. For example, psychological knowledge is rooted in perceptual experience not in the sense that it is about mental phenomena that are presently perceived (which is obviously not the case), but in the sense that the psychologist presently perceives her act of remembering the phenomenon her knowledge is about, that is, an act in which the object of psychological knowledge appears in another mode than perception. Brentano's theory of intentionality seeks to clarify how some objects - as "intentional objects" - appear and are objects of knowledge without existing. ${ }^{8}$

\section{References}

Albertazzi, L. (1986). Fritz Mauthner: La critica della lingua. Lanciano: Carabba.

Albertazzi, L. (1989). Brentano and Mauthner's critique of language. Brentano Studien 2:145159.

Albertazzi, L. (1990). Nominalismo e critica della lingua in Franz Brentano. Idee 13/15: 217 232.

\footnotetext{
${ }^{7}$ Mauthner rejects the idea of a non-linguistic knowledge. See (Weiler 1970: 292).

${ }^{8}$ I have developed this interpretation of Brentano's theory of intentionality in (Seron 2017a; Seron 2017b; Seron 2019).
} 
Albertazzi, L. (1996). Anton Marty 1847-1914. In: The School of Franz Brentano (L. Albertazzi, M. Libardi, R. Poli, Eds.). Dordrecht: Springer.

Albertazzi, L. (2006). Immanent Realism: An Introduction to Brentano. Dordrecht: Springer.

Berlage, A. (1994). Empfindung, Ich und Sprache um 1900: Ernst Mach, Hermann Bahr und Fritz Mauthner im Zusammenhang. Frankfurt Berlin Bern New York Paris Wien: Peter Lang.

Bredeck, E. (1992). Metaphors of Knowledge: Language and Thought in Mauthner's Critique. Detroit: Wayne State University Press.

Brentano, F. (1970). Versuch über die Erkenntnis. Hamburg: Meiner.

Brentano, F. (1973). Psychologie vom empirischen Standpunkt. Hamburg: Meiner. Engl. transl. by A.C. Rancurello, D.B. Terrell, L.L. McAlister: (1995) Psychology from an Empirical Standpoint. London and New York: Routledge.

Brentano, F. (1977). Die Abkehr vom Nichtrealen. Hamburg: Meiner.

Brentano, F. (EL80). Logik: Vorlesingsmanuskript (R. Rollinger, Ed.). Graz: Franz Brentano Archiv. URL: http://gams.unigraz.at/archive/objects/context:bag/methods/sdef:Context/get?mode=logik

Cesalli, L., \& Mulligan, K. (2017). Marty and Brentano. In: The Routledge Handbook of Franz Brentano and the Brentano School (U. Kriegel, Ed.). New York: Routledge.

Gakis, D. (2012). Contextual Metaphilosophy: The Case of Wittgenstein. Amsterdam: ILLC.

Huemer, W. (2018). Franz Brentano. In: The Stanford Encyclopedia of Philosophy (Fall 2018 Edition) (E.N. Zalta, Ed.). URL: https://plato.stanford.edu/archives/fall2018/entries/brentano/

Kastil, A. (1951). Die Philosophie Franz Brentanos: Eine Einführung in seine Lehre. Bern: A. Francke.

Kraus, O. (1929). Selbstdarstellung. Leipzig: Meiner. (Separate reprint from Die Philosophie der Gegenwart in Selbstdarstellungen, Vol. 7, pp. 161-203.)

Le Rider, J. (2012). Fritz Mauthner : Scepticisme linguistique et modernité. Une biographie intellectuelle. Paris: Bartillat.

Libardi, M. (1996). Franz Brentano (1838-1917). In: The School of Franz Brentano (L. Albertazzi et al., Eds.). Dordrecht: Kluwer, pp. 25-79.

Mauthner, F. (1901-2). Beiträge zu einer Kritik der Sprache. Stuttgart: J.G. Cotta. Bd. I, 1901: Zur Sprache und zur Psychologie; Bd. II, 1901: Zur Sprachwissenschaft; Bd. III, 1902: Zur Grammatik und Logik. 
Mauthner, F. (1906). Die Sprache. Frankfurt a. M.: Rütten u. Loening.

Mauthner, F. (1910). Wörterbuch der Philosophie: Neue Beiträge zu einer Kritik der Sprache, Vol. 1. München Leipzig: Georg Müller.

Mauthner, F. (1922). Fritz Mauthner. In: Die Philosophie der Gegenwart in Selbstdarstellungen. Leipzig: Meiner, pp. 121-144.

Nájera, E. (2007). Wittgenstein versus Mauthner: Two critiques of language, two mysticisms. Papers of the 30th International Wittgenstein Symposium 5-11 August 2007 (H. Hrachovec, A. Pichler, J. Wang, Eds.). Kirchberg am Wechsel: ALWS.

Scheler, M. (1914). Review of (Mauthner 1901-2), Vol. 3 (2d edition). Die weissen Blätter, 6, pp. 118-119.

Seron, D. (2017a). Brentano's project of descriptive psychology. In: The Routledge Handbook of Franz Brentano and the Brentano School (U. Kriegel, Ed.). New York: Routledge, pp. 35-40.

Seron, D. (2017b). Brentano on appearance and reality. In: The Routledge Handbook of Franz Brentano and the Brentano School (U. Kriegel, Ed.). New York: Routledge, pp. 169177.

Seron, D. (2019). Intentionality vs. psychophysical identity. In: Ernst Mach - Life, Work, and Influence / Ernst Mach - Leben, Werk und Wirkung (F. Stadler, Ed.). Springer.

Vaihinger, E. (1922). Die Philosophie des Als-Ob: System der theoretischen, praktischen und religiösen Fiktionen der Menschheit auf Grund eines idealistischen Positivismus, 7th and 8th edition. Leipzig: Meiner.

Voltaire (1879). Zadig. In: Oeuvres completes. Paris: Garnier, Vol. 21, pp. 31-93. Engl. transl. by R. Pearson: (2006) Candide and Other Stories. Oxford: Oxford University Press, pp. 107-177.

Weiler, G. (1958). On Fritz Mauthner's critique of language. Mind, 67 (265): 80-87.

Weiler, G. (1970). Mauthner's Critique of Language. London: Cambridge University Press. 